\title{
The Impact of Using CTL-Based Comic Media on Learning Outcomes of Third Grade Students
}

\author{
Dewi Sartika Panggabean \\ Basic Education Study Program, Postgraduate School \\ State University of Medan \\ Medan, Indonesia \\ E-mail: tea_kha21@yahoo.com
}

\author{
Mutsyuhito Solin \\ Lecturer of Postgraduate School \\ State University of Medan \\ Medan, Indonesia
}

\author{
Zulkifli Matondang \\ Lecturer of Postgraduate School \\ State University of Medan \\ Medan, Indonesia
}

\begin{abstract}
This research was conducted to know the impact of using CTL-based comic media on learning outcomes of third grade students of Private Elementary School of Nurul Hasanah Tembung using the material on the sub-theme "My Rights and Obligations". Type of research was a QuasiExperimental Design with Nonequivalent Control Group Design. The sample was students of IIIA class as the experiment class and IIIB class as the control class. Based on the posttest data analysis using the Mann-Whitney test, Sig values obtained at $0.000<$ 0.05 that meant there were differences in learning outcomes between students who learn using CTLbased comic media with students who learn without using CTL-based comic media. Comic based on CTL gave effect by $26.03 \%$ to increase learning outcomes of student in the material on the sub-theme "My Rights and Obligations".
\end{abstract}

Keywords-Comic Media, CTL, Learning Outcomes, Indonesian Language Subject

\section{INTRODUCTION}

Language is the main communication tool which is the main key to interact between humans in social life. Language learning aims to improve language skills, thinking abilities, express ideas, feelings, opinions, approvals, desires, communication skills both oral and written, delivery of information about a matter and the ability to broaden horizons. One of the goals of learning languages is learning to communicate. Therefore, language learning is directed at students' ability to communicate well in Indonesian language, both orally and in writing.

Indonesian language is one of the main subjects in elementary schools. Indonesian subjects are taught to students from grade I to grade VI. According to Lely Halimah, Indonesian Language lessons in elementary schools should ideally be a means for students to develop communicative abilities [1]. However, based on researchers 'interviews with the third grade teacher at Private Elementary School of Nurul Hasanah Tembung, where the results of students' daily tests were still far from expectations. The average daily results of students have not reached the specified value standard, which is 70. Ms. Elly Nurhayati Purba as a classroom teacher stated that only $25 \%$ of students who complete in learning.

Nana Sudjana in his book stated "Learning outcomes are abilities possessed by students after he received his learning experience" [2]. Basically the result of learning is a new skill and behavioral ability that is obtained as a result of practice or experience. Learning ability of students is the final product of a teaching and learning process. Therefore, in the ability of learning outcomes there is a classification assessment to achieve student learning outcomes.

Learning is a complex process and involves various interrelated aspects. The learning process is a communication process [3]. The essence of the learning process in Elementary Schools/Islamic Elementary Schools (Madrasah Ibtidaiyah) is concrete learning, namely learning that is carried out logically and systematically, learning with regard to events in the environment around students. In the learning process a good communication component is needed to deliver messages from the teacher to students. With the good communication component in the learning process, the message to be conveyed by the teacher will be well received by students. One way that can be used to achieve this is by using learning media.

The use of instructional media aims to make it easier for teachers to deliver subject matter to 
students so that activities in learning will be more meaningful. Students will more easily understand teaching materials with the help of media [4]. Azhar Arsyad said that one of the functions of the use of media in learning is to clarify the presentation of messages and information so as to improve the process and student learning outcomes [5]. Therefore, the presence of media in the learning process can simplify the complexity of the material that will be conveyed to students.

According to Gagne, the media are classified into seven groups namely objects to be demonstrated, oral communication, print media, static images, moving images, sound films and machine learning [3]. There are many kinds of learning media that can be used in the learning process. But in reality in implementation, the learning media used by Private Elementary School of Nurul Hasanah Tembung were only Student Worksheets (LKS) and textbooks. As many as $70.17 \%$ of students stated that the Student Worksheets (LKS) used at school were less attractive and had difficult language to understand. The students' lack of understanding and disinterest in the Student Worksheet (LKS) caused students to be lazy and bored to read it. Based on the results of interviews with teachers, basically third grade elementary school students have a fairly high interest in reading, but the readings are non-fiction such as short stories, stories and comics. This statement is in line with the questionnaire responses of students to Indonesian language textbooks, which states the hobby of reading comics with a percentage of $70.17 \%$. The high percentage of students' interest in reading comics can be used to improve student learning outcomes towards learning Indonesian.

According to Mc Cloud, "comics are drawings and other symbols are contiguous or adjacent in certain utterances which aims to deliver information and achieve aesthetic responses from reades" [6]. According to Sujana, "comic is a form of cartoon that expresses characters and plays a story in a sequence that is closely connected with images to provide entertainment and knowledge to its reader" [7]. Comic is a form of art that does not use moving pictures that are arranged in such a way as to shape and construct the storyline.

Comic is very effective when applied to low age children, such as kindergarten and low class student of elementary school. Comic is loved by young to old people. Meier said, "more than $90 \%$ of students are comic readers" [8]. Thus it is evident that comic is one of the most preferred reading materials by children and students.

Comic aside from functioning as entertainment media, it can also be used effectively to increase reading interest, develop vocabulary and reading skills and can also be used as effective media for learning purposes [5], such as improving the learning outcomes of Indonesian students in low grades. According to Wurianto, comic media has five benefits, namely: 1) increasing motivation in learning, 2) cartoon images in comics can improve the quality of learning, 3) can make students' memories permanently, 4) can increase interest in reading and direct students to discipline reading especially in students who are not fond of reading, and 5) comics are ideas or ideas part of popular culture [9].

The use of comic media as Indonesian language learning media has an important role because the presentation of comics can bring students in an atmosphere of excitement, especially in the aspect of reading. Comics as learning media must be adjusted to the characteristics of elementary school students. The average elementary school age student still has a visual style that tends to activate objects or images captured by the sense of sight. Elementary school students have high curiosity, think systematically and logically when dealing with concrete information that is received directly [8].

The learning approach that focuses on the activeness of students in participating in learning activities is Contextual Teaching And Learning (CTL). Learning with the CTL approach, students are actively invited to be able to connect the contents of the material with the context of students' daily lives, to provide understanding and full meaning [10]. According to Elaine B. Johnson, "CTL learning is an educational process that aims to help students see interpretations in academic material that they learn by connecting academic subjects with the context of their daily lives, namely the context of their personal, social and cultural circumstances" [ 11]. The CTL approach is an approach that encourages students to be active in the learning process in order to find learning concepts, by linking the material knowledge they have with students' experiences in daily life. By reading CTL-based comics, students will easily understand the material on the sub-theme "My Rights and Obligations". Students will better understand what they see compared to just hearing the explanation by the teacher. The use of CTLbased comic media in learning is expected to provide a new atmosphere for students so that learning is more interesting and enjoyable. In addition, CTL-based comic media are also expected to be able to improve student learning outcomes.

The success of integrating comic media with the learning approach can be seen from previous research conducted by Ais Rosyida, Mustaji, and Waspodo Tjipto Subroto showed that CTL-based comic media is feasible, practical and effective to improve learning outcomes of third grade students of elementary schools in social studies subjects [12]. Even Ade Irma S. in his research showed that 
comic media with role playing affect the results and students' interest in learning about virus material. [13]. Thus, learning Indonesian language is also very suitable when integrating comic media with the CTL approach in learning.Based on the background of the problem, the problem to be examined is, "is the impact of CTL-based comic media better than the normal learning process on student learning outcomes?"

\section{METHOD}

This type of research is a quasi-experimental study. This research was carried out at Private Elementary School of Nurul Hasanah Tembung. The population in this study were all grade III students of Private Elementary School of Nurul Hasanah Tembung. Sampling with purposive sampling technique, where class III $\mathrm{A}$ as an experiment class and class III B as a control class. This study used a pretest-posttest control group design.

$\begin{array}{llcc}\text { Experiment } & \mathrm{T}_{1} & \mathrm{X} & \mathrm{T}_{2} \\ \text { Control } & \mathrm{T}_{1} & - & \mathrm{T}_{2}\end{array}$

Information:

$\mathrm{X}$ : Learning with CTL-based comic media

$\mathrm{T}_{1} \quad$ : Pre-test

$\mathrm{T}_{2} \quad$ : Post-test

Data collection instrument was a test of student learning outcomes in the form of essay questions. The calculation of the validity and reliability of the instrument was tested on 30 students. The test results on student learning outcomes are valid as many as 10 questions with a reliability coefficient of 0.75 . Hypothesis testing was performed using the Mann-Whitney Test with the help of SPSS 20.0. The Mann-Whitney test was used because both the pretest and posttest data groups of experimental and control class students were not normally distributed. The magnitude of the impact arising from the use of comic media was measured by the formula effect size according to Glass, namely:

$$
\Delta=\frac{M_{1}-M_{2}}{\sigma_{\text {kontrol }}}
$$

Information:

\section{$\Delta \quad$ : Effect Size \\ Mi : Mean or Average Experiment Class \\ M2 : Mean or Average Control Class \\ $\sigma_{\text {kontrol }}$ : Deviation Standard of Control Class}

Interpretation of effect size according to Glass, as follows:

ES $<0,3 \quad$ : classified low

$0,3 \leq \mathrm{ES} \leq 0,7$ : classified moderate

ES $>0,7 \quad:$ classified high
The magnitude of the impact of the use of CTL-based comic media on learning outcomes was done by entering the price of the calculated effect size into a large table under the normal curve of the standard $\mathrm{O}$ to $\mathrm{Z}$ then multiplied by $100 \%$.

\section{RESULTS AND DISCUSSION}

A. Pretest and Posttest Experiment Class Students

In this study the experiment class was class III A with 37 students. This class was given treatment in the form of learning with comic media based on CTL. Learning in the experiment class was conducted in one meeting (70 minutes) which was divided into three stages of activity, namely the initial stages of learning, the core stages of learning and the closing stages of learning.

Pretest in the experiment class was given one day before learning activities began. Pretest was given to know the students' initial knowledge of the material. Posttest was held on the same day to find out the students' knowledge after participating in the learning. The test given in the form of essay questions consisted of 5 questions and the time provided for working on the test was 20 minutes.

Based on the results of the pretest and posttest assessment of the experiment class students, the data obtained are presented in the following table.

TABLE I. DATA ON STUDENT LEARNING OUTCOMES OF EXPERIMENT CLASS

\begin{tabular}{|c|c|c|c|c|c|}
\hline & \multirow[b]{2}{*}{$\begin{array}{l}\text { Average } \\
\text { Score }\end{array}$} & \multicolumn{2}{|c|}{ Total Students } & \multicolumn{2}{|c|}{ Percentage $(\%)$} \\
\hline & & Compeleted & $\begin{array}{l}\text { Not } \\
\text { Compe } \\
\text { leted }\end{array}$ & $\begin{array}{l}\text { Com } \\
\text { pleted }\end{array}$ & $\begin{array}{l}\text { Not } \\
\text { Compeleted }\end{array}$ \\
\hline Pretest & 11,16 & 0 & 37 & 0 & 100 \\
\hline Posttest & 70,59 & 25 & 12 & 67,57 & 32,43 \\
\hline
\end{tabular}

Based on Table 1. it can be seen that none of the students completed the pretest but overall none of the students got a zero grade. Twenty students completed the posttest on the sub-theme material "My Rights and Obligations" because the students had followed the learning using CTL-based comic media. H. D. Waluyanto, stated that comics combine the power of images and writing arranged in a story line, pictures make information more easily absorbed, text makes it easier to understand, and the plot makes it easier to follow and remember [14].

Table I also showed an increase in the average value of learning outcomes obtained by students from before being given after being given learning with comic media on the sub-theme 
material "My Rights and Obligations". According to H. D. Waluyanto, comic is one of the visual media that can convey messages or material clearly, coherently, and pleasantly [14]. Submitting clear, coherent and enjoyable learning material can help maximize the learning process so that the results achieved will be maximized [15]. Thus, it can be concluded that the increase in student learning outcomes of the experiment class on the material sub-theme "My Rights and Obligations" occurs due to the use of comic media.

\section{B. Pretest and Posttest Control Class Students}

In this study the control class was class III B with 38 students. This class was given treatment in the form of ordinary learning and using thematic textbooks as a medium of learning. Learning in the control class was conducted in one meeting (70 minutes) which was divided into three stages of activity, namely the initial learning phase, the core learning phase, and the closing phase.

Pretest in the control class was done one day before learning activities began. Pretests were given to measure students' initial knowledge of the material "My Rights and Obligations". Posttests were held on the same day as the treatment (learning with conventional methods). Posttest was given to measure students' knowledge after participating in learning. The tests (pretest and posttest) given in the form of essay questions consisted of 5 questions and the time provided for taking the test was 20 minutes.

Based on the results of the pretest and posttest scores of the control class students, the data obtained are presented in the following table.

TABLE II. DATA ON STUDENT LEARNING OUTCOMES OF CONTROL CLASS

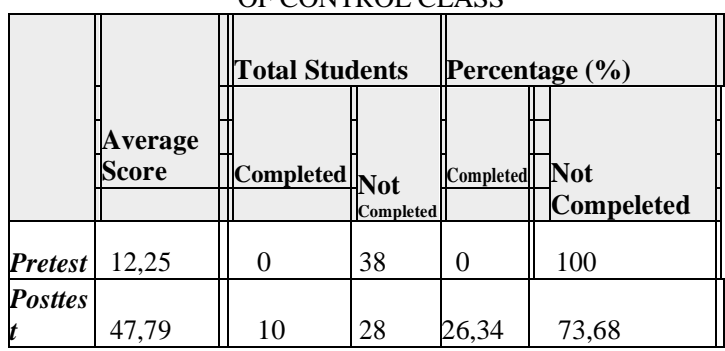

Based on Table 2, it can be seen that none of the students completed the pretest, but overall none of the students got zero marks. A total of eight students completed the posttest on the sub-theme material "My Rights and Obligations".

Table II also showed an increase in the average value of learning outcomes obtained by control class students from before being given to after being given learning with thematic textbooks on the sub-theme material "My Rights and Obligations". Textbooks are one of the learning media that can help deliver learning messages [16]. According to Nana Sudjana and Ahmad Rivai, the use of teaching media can enhance learning outcomes achieved [17]. It was concluded that the improvement in the learning outcomes of control class students on the sub-theme "My Rights and Obligations" occurred due to the use of thematic textbooks.

In this study the increase in the learning outcomes of the control class students was not as great as the increase in the learning outcomes of the experiment class students. Based on Table 1 showed that the difference in the average pretest and posttest of the experiment class was greater that was 59.43 and based on Table 2 the average difference in the pretest and posttest of the control class was 35.54 .

Using the SPSS 20.0 program, the results of the Mann-Whitney test statistics can be seen in the following table.

TABLE III. MANN-WHITNEY POSTES TEST RESULTS IN THE EXPERIMENT CLASS AND CONTROL CLASS

\begin{tabular}{|l|r|}
\hline Test Statistics $^{\text {a }}$ & questionnaire \\
\hline Mann-Whitney U & 268,500 \\
Wilcoxon W & 829,500 \\
Z & $-3,545$ \\
Asymp. Sig. (2-tailed) &, 000 \\
\hline
\end{tabular}

a. Grouping Variable: Class

In Table 4, based on the results of the MannWhitney statistical test above, it was known that the Asymp value, Sig. (2-tailed) of 0,000 was smaller than the probability value $(\alpha=0.05)$, so the probability $<0.05$, it can be concluded that $\mathrm{H} 0$ was rejected, which meant that the experiment class and control class students' tests were different. The difference in learning outcomes between the experiment class and the control class occured because the learning media used in the two classes were different. In the experiment class the media used are CTL-based comics. Unlike the control class where students were only given a textbook. According to Suharsimi Arikunto, other factors that might cause learning outcomes between students of the experiment class and the control class are physical conditions and learning strategies undertaken by the teacher and the environment, ie who and what intentionally or unintentionally affected the level of student learning outcomes [ 18].

\section{The Impact of Using CTL-Based Comic Media on Learning Outcomes}

The magnitude of the impact of using CTLbased comic media to increase student learning outcomes in the sub-theme "My Rights and Obligations" was seen from the size of the effect size. Based on the calculation results, the effect size of the price was 0.74 which was included in the high category. Referring to the broad table 
under the standard normal curve from $\mathrm{O}$ to $\mathrm{Z}$, the percentage increase in student learning outcomes in the experimental class due to the impact of CTL-based comic media was $26.03 \%$. This showed that the use of comic media based on CTL in the sub-theme "My Rights and Obligations" had a high impact on improving student learning outcomes in third grade Private Elementary School of Nurul Hasanah Tembung.

The high impact of the use of CTL-based comic media on learning outcomes was due to several advantages, such as comics preferred by third grade students of Private Elementary School of Nurul Hasanah Tembung compared to Student Worksheets (LKS)/thematic textbooks, the packaging is able to attract students' attention and the presentation of the material is clear and easy to understand. According to Beard and Rhodes, the use of comics in the learning process can stimulate students' motivation and interest in a subject that is considered difficult and also can build understanding [15]. Hoyun Cho and Gary D. Lawrence, stated that comic has the potential to be used as an educational tool, especially in arousing student interest in learning [19]. According to Syaiful Bahri Djamarah, great interest in learning tends to result in high learning achievement, whereas less interest in learning will result in low learning achievement [20].

\section{CONCLUSION}

Based on the results of the analysis and discussion of the study it can be concluded that, there are differences in learning outcomes between students learning to use CTL-based comic media and students who study without using comic media on the sub-theme material "My Rights and Obligations". The use of comic media based on CTL gives an effect of $26.03 \%$, to the improvement of the learning outcomes of third grade students at Private Elementary School of Nurul Hasanah Tembung on the sub-theme "My Rights and Obligations".

\section{ACKNOWLEDGMENT}

Thank you, the writer, for the supervisors who have provided direction for the improvement of this research. Thanks also to the principal of Private Elementary School of Nurul Hasanah Tembung, the teachers, students and friends involved in this research.

\section{REFERENCES}

[1] L. Halimah, "Pengembangan Model Pembelajaran Bahasa Secara Utuh untuk Meningkatkan Kompetensi Komunikatif", Vol. 26, No. 3, 2007, hlm. 31-34.

[2] N. Sudjana. 2001. Penilaian Hasil Proses Belajar Mengajar. Bandung: PT Remaja Rosdakarya.

[3] Daryanto. 2016. Media Pembelajaran. Yogyakarta: Gava Media.

[4] O. Hamalik. 2006. Media Pendidikan. Jakarta: Grafindo Persada.

[5] A. Arsyad. 2013. Media Pembelajaran. Jakarta: PT Raja Grafindo Persada.

[6] D. Yulianti, S. Khanafiyah, and S. Sulistyorini, "InquiryBased Science Comic Physics Series Integrated With Character Education", JPII, Vol. 5, No. 1, 2016, pp. 38-44.

[7] M. Sari, I. Azhari, Yusnadi, "Developing Comic as Learning Media with Sub-Theme "The Beauty of My Country's Cultural Diversity" on Social Science in Class IV of SDN 026609 Binjai Selatan", International Journal of Education, Learning and Development, Vol. 7, No. 3, 2019, pp. 180-192.

[8] D. Musfiroh, "The Effect of Using Comic Media Towards $5^{\text {th }}$ Grade Student's Story Telling Skill at SDN Sinduadi 1", Jurnal Pendidikan Guru Sekolah Dasar, Edisi 21, Tahun ke-7, 2018, pp. 2044-2053.

[9] R. Suciningrum, "Classroom reading helped programs for comic media to improve the interest of reading basic school students", $1^{\text {st }}$ Nasional Seminar on Elementary Education (SNPD), Vol. 1, No. 1, 2018, pp. 705-710.

[10] D. Selvianiresa and S. Prabawanto, "Contextual Teaching and Learning Approach of Mathematics in Primary School", ICMScE, 2017, pp. 1-7.

[11] E. B. Johnson. 2007. Contextual Teaching and Learning. Bandung: MLC.

[12] A. Rosyida, Mustaji, dan W. T. Subroto, "Pengembangan Media Komik Berbasis CTL Untuk Meingkatkan Hasil Belajar Siswa Sekolah Dasar", Jurnal Kajian Pendidikan dan Hasil Penelitian, Vol. 4, No. 3, 2018, hlm. 1-10.

[13] A. I. S., "Pengaruh Media Komik dengan Role Playing Terhadap Hasil dan Minat Belajar Siswa pada Materi Virus di MIN 1 Sigli”. Skripsi. Banda Aceh: Universitas Islam Negeri Ar-Raniry. 2017.

[14] H. D. Waluyanto, "Komik Sebagai Media Komunikasi Visual Pembelajaran", 2005, Online, (http://puslit2.petra.ac.id/gudangpaper/files/2266.pdf)

[15] A. N. Wahyuningsih, "Pengembangan Media Komik Bergambar Materi Sistem Saraf Untuk Pembelajaran yang Menggunakan Strategi PQ4R", Jurnal PP, Vol. 1, No. 2, 2011, hlm. 102-110.

[16] R. Susilana dan C. Riyana. 2009. Media Pembelajaran Hakikat, Pengembangan, Pemanfaatan, dan Penilaian. Bandung: Wacana Prima.

[17] N. Sudjana dan A. Rivai. 2013. Media Pengajaran. Bandung: Sinar Baru Algensindo.

[18] S. Arikunto. 2013. Evaluasi Hasil Belajar. Jakarta: Rineka Cipta.

[19] Hoyun Cho, dan Gary D. Lawrence. 2012. Using of Comics to Increase Interest and Motivation. International Congress on Mathematical Education. Seoul. 8-15 Juli.

[20] S. B. Djamarah. 2002. Strategi Belajar Mengajar. Jakarta: Rineka Cipta. 